\title{
Digital Entrepreneurship Perspective of Smart Organization and Technological Innovation: A Conceptual Model
}

\author{
Mushira A. Eneizat ${ }^{1} \&$ Mohammed Mufaddy Al-Kasasbeh ${ }^{1}$ \\ ${ }^{1}$ Faculty of Business and Finance, The World Islamic Sciences and Education University, Jordan \\ Correspondence: Mushira A. Eneizat, Faculty of Business and Finance, The World Islamic Sciences and \\ Education University, Jordan. E-mail: menezat@taguci.edu.jo
}

\author{
Received: March 3, $2021 \quad$ Accepted: April 6, $2021 \quad$ Online Published: May 22, 2021 \\ doi:10.5539/jms.v11n2p32 URL: https://doi.org/10.5539/jms.v11n2p32
}

\begin{abstract}
To be successful in today's rapid and increasing changes, innovation is the only option for maintaining growth and competitiveness. Organizations actually need to become "smart" to confront the growing customer needs, and changing markets. Digital entrepreneurship (DE) is perceived as a key pillar for innovation. However, there are a number of concerns surrounding smart organization (SO), DE, and technological innovation (TI), and how they are related is complex and important to understand in this digital age.

While the extant literature presents several models for innovation, however, these studies are considered to be incomplete as they do not emphasize the relation between these variables. Based on conducting a deep literature review, this study proposes a conceptual model for SO focusing on TI (i.e., Product and process). This integrated model argues that SO's components namely business intelligence, creative orientation, environment understanding, adaptation, and continuous learning significantly contribute to TI. In addition, it proposes that DE mediates the relationship between the SO and TI. Hypotheses development and suggesting further areas of research are discussed.
\end{abstract}

Keywords: digital entrepreneurship, smart organization, technological innovation

\section{Introduction}

In the last century, the economic performance and countries' innovation success has broadly relied on the advancement of digital technology (Konig, Ungerer, Baltes, \& Terzidis, 2919). Widely, digitalization is associated with the changes related to big data analytics, cloud computing, the adoption of digital technologies, and intensity in their usage (Parviainen, Kääriäinen, Tihinen, \& Teppola, 2017). Research reveals that the rates of digitalization continue to grow in today's environment that characterized by uncertainty, market challenges, the workforce's continual demographics changes, and social, political, economic volatile changes in addition to the competition ferocity (Parviainen et al., 2017; Satalkina \& Steiner, 2020).

Thus, in this turbulent situation, innovation is the only choice for sustaining growth and competitiveness, organizations really need to become "smart" (i.e., internetworked, knowledge-driven, able to adapt, learning continually, creative, understand the surrounded environment, flexible in their ability to create home-grown innovative ideas and exploit both external and internal available opportunities (El Haiba, Elbassiti, \& Ajhoun, 2017; Teece, Peterar, \& Leih, 2016). Indeed, organizations have to innovate continuously in order to thrive (El Bassiti and Ajhoun, 2013). The SO, as a novel organizational shape, is in fact the result of all transformations mentioned above. This notion actually emerged from the firms' and enterprises' urgent need to respond to the progressively changing business landscape in dynamic, innovative, and smarter manners (El Haiba et al., 2017).

The concept SO is therefore utilized for firms that are internetworked, knowledge-driven, dynamically adaptive to novel organizational forms and practices, learning as well as agile in their capability to generate and exploit the opportunities offered by the new economy, in addition to their innovation and creativity capabilities (Filos \& Banahan, 2001; Atos, 2011), indicated that the SO is established on three major axes, namely, development of knowledge, operations, and communication.

Digital technologies have become a new economic and social force, reconfiguring traditional business paradigms, strategies, structures as well as processes and activities (Beliaeva, Ferasso, Kraus, \& Damke, 2019). Entrepreneurship, in its simplest shape, can be characterized as self-employment (Gohmann, 2012). DE, which 
focuses on constructing new ventures, transforming existing businesses by developing novel digital technologies or their novel use, is seen as a crucial pillar for economic growth, job creation, and innovation by many states (Liliya \& Gerald, 2020). On the other hand, DE varies from this definition seeing as it contains entrepreneurial pursuits that occur on a digital platform (Giones \& Brem, 2017). DE have a dependence on digital media tools and Information Technology (IT) in the pursuit of entrepreneurial prospects (Giones \& Brem, 2017).

Innovation is a means of changing an organization, whether as a response to changes in its internal or external environment or as a preventative action taken to impact and/or be affected by the environment (Demircioglu, 2016). Moreover, the capacity of a firm to innovate is a pre-condition for the successful use of inventive resources and novel technologies (Demircioglu, 2016a). Innovation includes a creative climate, learning, knowledge sharing, cooperation, and risk-taking (Damanpour, 1991). Successful firms not only respond to their existing customer or organizational needs but also foresee future trends and develop an idea, product, service, process, or tools that permit them to meet future demand rapidly and effectively (Liliya et al., 2020). Types of innovation contain but not limited to product (goods and services), process, marketing, and organizational innovation (Elerud-Tryde \& Hooge, 2014).

SO, innovation, entrepreneurship, and digital transformation are ever-present, work is increasingly being virtualized, digitalized, or even totally automated (Davenport \& Kirby, 2015). Innovation processes themselves are becoming less bounded, more open, less predictable, and more agile (Youngjin, Richard, Kalle, \& Ann, 2012; Majchrzak \& Markus, 2014; Nambisan, 2017). Due to the influence of new digital technology on entrepreneurship and vice versa, new shapes of projects and organizations have emerged smarter and more flexible, and adaptable (Nambisan, 2017; Autio \& Rannikko, 2018; Von Briel, Davidsson, \& Recker, 2018a; Von Briel, Recker, \& Davidsson, 2018b).

Nevertheless, there is no work considering two or more determinants of innovation at the same time, i.e., no study takes into account prominent factor collections (e.g., independent variable and mediator and/or independent variable) together as far as researchers know. Therefore, the present study purposes to suggest an integrated conceptual model for the relationship between the variables (i.e., SO, DE, and TI). Given the limited research in this arena, this model is a strong basis for discussion, criticism, and/or support of future research.

The remainder of the paper is structured as follows: in Section. 2 we provide a theoretical lens to the study presenting an overview of the SO (Sect. 2.1), DE (Sect. 2.2), and TI (Sect. 2.3). The conceptual model development to this study is discussed in Section. 3, by presenting a literature review and hypotheses development on SO and TI (sec. 3.1), SO and DE (sec. 3.2), the mediating effect of DE (Sec. 3.3), and present the conceptual model. Finally, we draw conclusion and indicate directions for future research in Section 4.

\section{Theoretical lens}

\subsection{SO: Definition and Conceptualize}

Nowadays, the concept of the SO is utilized to describe organizations that are knowledge-driven, interconnected, networked, dynamically adaptive (Vickers, 2000), and quick response to new organizational forms and emerging practices (Chan, 2006, p. 102), as well as willing to generate and exploit the opportunities offered by the digital age (Matheson \& Matheson, 2001). From a managerial viewpoint, the term SO seems to be arising from the book "Smart Organization: Creating Value through Strategic R\&D" which was written by David Matheson and James Matheson in 1997 (Matheson \& Matheson, 1997; Petković \& Lukić, 2014). Bearing that in mind, it is obvious that SO of the 21 st century will be those organizations that utilize the whole available resources to become better, faster, smarter, and more rigorous at many core activities and successfully utilize intensively technologies to provide innovative products and processes (Wasterman, Bonnet, \& McAfee, 2014).

Actually, what does it really mean to be a "SO"? and the characteristics of such new organizational forms are not yet well defined (Irwin \& Cichocki, 2011; Petković \& Lukić, 2014; Petković \& Lukić, 2013). However, (Matheson \& Matheson, 1997, pp. 96-98) stated that SO have nine basic principles that make them smart (Figure 1), those principles are intangible and embedded in the philosophy, people, culture, and organization's support systems (Petković \& Lukić, 2014). 


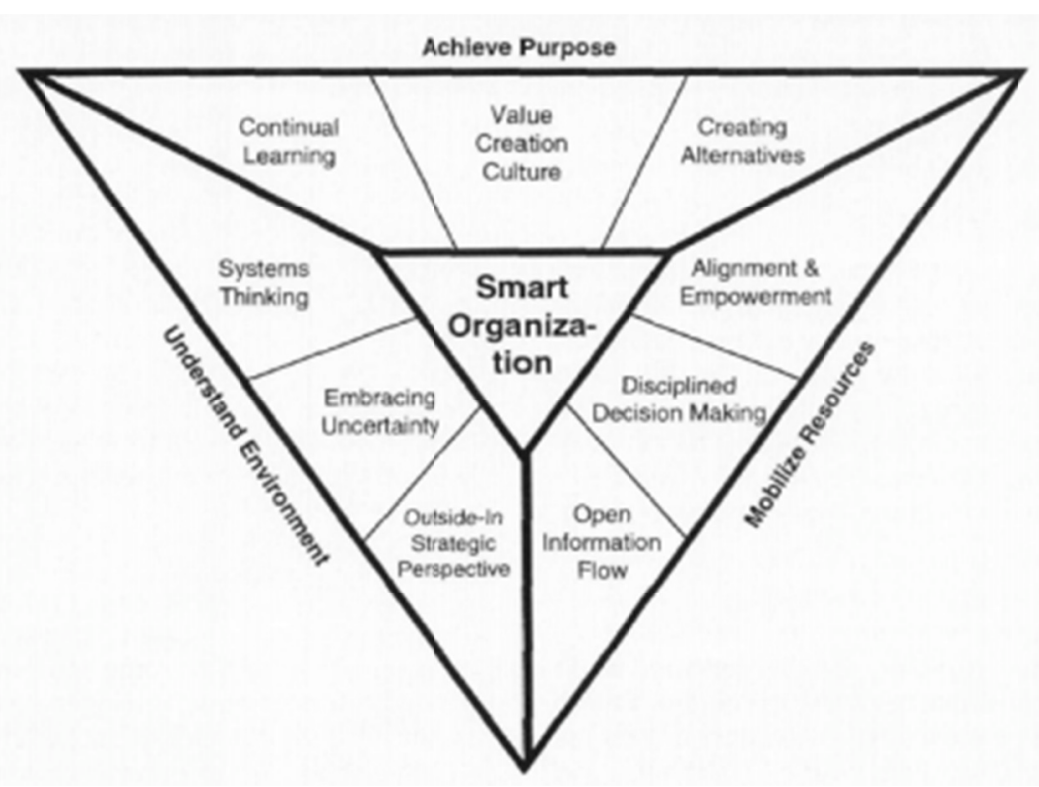

Figure 1. SO's nine principles (components)

Source: Matheson and Matheson, 2001; Petković and Lukić, 2013; Petković and Lukić, 2014; Mark A. Schafer, 2009.

Guided by the study purpose, this study builds on (Matheson \& Matheson, 2001) SO's nine components and also many previous works of literature, for example (El Haiba et al., 2017; Avin \& Jakar, 2018; Petković \& Lukić, 2014; Petković \& Lukić, 2013; Al-Kasasbeh, Al-Kasasbeh, \& Al-Faouri, 2016; Al Shobaki, Abu Naser, Abu Amuna, \& El Talla, 2018; Mark, 2009) that describe the SO's components (namely business intelligence, creative orientation, environment understanding, adaptation, and continuous learning).

\subsection{DE: Definition and Conceptualize}

$\mathrm{DE}$ is a term that describes how entrepreneurship will shift as business and society go on to be transformed thru digital technology (Davidson \& Vaast, 2010). DE highlights transformations in entrepreneurial practice, theory, and education (Matt, Hess, \& Benlian, 2015). DE includes everything that is new and different about entrepreneurship in a digital world, including novel ways of finding customers for entrepreneurial ventures, designing and presenting products and services, innovation, creativity, generating revenue and minimizing costs, opportunities to collaborate with platforms and stakeholders, opportunity sources, and risk-taking, and competitive edge (Joshua \& Smuts, 2020; Ebert \& Duarte, 2018; Nambisan, 2017; Davidson \& Vaast, 2010).

As per Mladen Turuk (2018, p. 179), DE most commonly refers to "the process of creating a new Internet-enabled/delivered business, product/service or process. DE is expanded to the traditional concept of entrepreneurship in the sense that it encompasses a group of participators that is continually developing and are highly distinguished, and they possess unique characteristics (Autio et al., 2018). This moves far from the traditionally established participant to a more ever-changing aggregation of participants who have their own, and differing, competencies, ambitions, and, in the end, objectives (Kraus et al., 2019), therefore, DE may belong to several business categories (Gohmann, 2012; Matt, Hess, \& Benlian, 2015). As digital technology progress and expanded, so too will these categories (e.g., marketing, sales, products, distribution, stakeholder management, operations), and new categories can potentially be fashioned (Rashidi et al., 2013).

\subsection{TI: Definition and Conceptualize}

In view of the rapid developments in the current era, there is an imperative need for innovation by organizations in order to keep pace with this development and survive despite the environmental dynamism in which they operate. Accordingly, much research focused on the relation between innovation and performance relationship, in particular TI (Damanpour \& Aravind, 2011). Innovation refers to a firm's tendency to engage in and support new ideas, experiment, and creative processes that may generate new products, services, or technological processes (Shan et al., 2016; Lumpkin \& Dess, 1996). According to Damanpour and Evan (1984, p. 394), TI refers to "the implementation of a creative idea for a new product or a new service or the introduction of new elements in an organization's production processes or service operations". 
For this reason, innovation considers the main entry for the future and a good indicator of the superior performance of an organization (Damanpour, Walker, \& Avellaneda, 2009). Innovation positively influences individuals, communities as well as business organizations, thru introducing new ways of performance, and products, services, and processes, and transfers individuals, organizations to a better position than the current one (Damanpour \& Wischnevsky, 2006). Damanpour (1991, p. 556) mentioned that "an innovation can be a new product or service, a new production process technology, a new structure or administrative system, or a new plan or program", these factors are also considered dimensions of innovation, in addition, innovations' kinds can be administrative vs. technical, product vs. process, and incremental vs. radical (Damanpour, 1991). Guided by the study purpose, this study builds on (Damanpour, 1991) classification that divides innovation into technological, product, and process.

\section{Conceptual Model Development}

This study aimed at investigating the relationship between the SO's components and TI (product and process) with an emphasis on the mediating effect of DE on this relationship. This section presents hypotheses development and conceptual model.

\subsection{SO and TI}

The SO enhances innovation by enabling communication in order to generate new knowledge and innovative idea to support the evolution of new products/processes (Bixler, 2005, p. 57). In their study, Andreas Kuckertz et al. (2015) empirically proved that an organization's flexibility and adaptability have a positive and meaningful effect on organizational innovation (i.e., innovation in the product, innovation in the process, technology innovation).

Organizational innovations are strongly associated with all the administrative efforts including renewing the organizational systems, procedures, routines, adaptability, creativity, encourage team cohesiveness, coordination, collaboration, information and knowledge sharing practice, and continuous learning (Van der Aa \& Elfring, 2002; Veugelers, 2008; Visnjic et al., 2016; Jayani \& Yan, 2018). In order for a firm to develop successful management of technology and innovation strategy, it is imperative that the organization be ready for the effort, this requires flexibility, smartness because changes and adjustments, and improvements in products and processes are usually filled with uncertainty and risk (Soltani, Azadi, \& Witlox, 2013). In this vein, developing employees thru training and continuous learning opportunities may affect product and process enhancement (Stock \& Reiferscheid, 2014).

Many scholars have suggested that the organization's capability to exploit external knowledge is a critical component of innovative capabilities (Cepeda-Carrion, Cegarra-Navarro, \& Jimenez-Jimenez, 2012), i.e., the organization's attempt to learn continually from external and internal sources can assist uncover new ideas, processes, or techniques that can be applied and foster innovation development and application (Nuno \& Coelhob, 2019). Business intelligence is "both a process and a product" (Nuno \& Coelhob, 2019), i.e., the process is composed of methods that enterprises utilize to evolve advantageous information or intelligence, that can assist firms to survive, thrive, and compete (AL-Shubiri, 2012), while the product is information that will permit enterprises to predict the behavior of their competitors, suppliers, customers, technologies, acquisitions, markets, products and services, and the overall business environment with a high degree of certainty, all these underline the business intelligence importance in the innovation systems (Berndtsson, Gudfinnsson, \& Strand, 2015).

According to Onizat and Alraggad (2020), knowledge creation and transfer within an organization affect TI (i.e., product and process innovation) which ultimately influence new product performance. Aviv Shoham et al. (2012) conducted a study in which they determined that innovativeness was a multidimensional construct, they defined five dimensions to measure organizational innovativeness, specifically: creativity, risk-taking, continuous learning, future orientation, openness to change, and proactiveness. Based on the aforementioned discussion, we can suggest the following proposition.

\section{Hypothesis 1 (H1): SO's components positively affect TI (product and process)}

\subsection{SO and $D E$}

Business intelligence influences firm performance directly and indirectly (Antoncic, Bostjan, Prodan, Igor, \& Alliances, 2008), directly as it enables entrepreneurship's innovative development dependent on the task interdependence in the firm, and indirectly thru effective knowledge management, efficient organizational learning processes, and increased technological innovation capabilities in the firm, all of these improvements materialize in data, business processes, and applications, which are in turn consider innovative forms of entrepreneurship (Štefan Bojnec, 2001). Regarding entrepreneurial organizations particularly, extant literature 
indicates that individuals will interact differently to the need to adapt to their environment, to learn continually, based on such factors as their psychological make-up and the existence of tangible incentives to change and support for innovative initiatives (Starr \& Nanette, 1992). In an information and technology-driven economy, innovation, flexibility, entrepreneurship, and creativity is a necessity for continuous learning, the results of Gozde Sezen-Gultekin and Duygu Gür Erdogan (2016) study indicated that there is a positive and meaningful relationship between continuous learning and entrepreneurship characteristics.

Study of Kandil, Abdul Auj, Al-Tarfy and Al-Shammari (2019) that aims to analyze the influence of the role of SO characteristics (strategic vision, the culture of merit, incentives, and rewards) in promoting entrepreneurial alertness by adopting proactive work behaviors of the application in Asia-Cell for mobile communication in Iraq, the findings reveal that the adoption of proactively work behaviors is instrumental in enhancing the relationship between organization's smart characteristics in achieving the company's entrepreneurial alertness and individual innovation

Bakhshian, Hamidi and Ezati (2011) stated that there a relationship between organizational intelligence and entrepreneurship among university educational managers. Ahmadi, Mohammad, Ranjbari and Meisam (2013) concluded that organizational intelligence affects entrepreneurship improvement. Adnisi and Mandla (2003) argue that there is a relationship between market orientation, organizational flexibility, and job satisfaction, and corporate entrepreneurship. Moreover, Faroun, Al-Anzi and Al-Khalidi (2015) emphasize the relationship between formulating an entrepreneurial strategy and develop a model for smart organizations. Hence, the following proposition was formulated as follows:

Hypothesis 2 (H2): SO's components positively affects DE

\subsection{DE and TI}

Arguably digitization nowadays is currently the single most significant engine in entrepreneurship and innovation (Elisabeth, Frederik, Per, \& Andreas, 2020). DE is a crucial driver within the innovation systems (Liliya \& Gerald, 2020). DE is a form of entrepreneurship that explains the practices of seeking out and/or identifying business opportunities that can be exploited, these practices include developing new products/services and processes, moreover, DE is perceived as a key pillar for economic growth, job creation, and innovation (Joshua \& Smuts, 2020).

According to Zahra and Covin (2005), the extant literature proves the hypothesis that organizational entrepreneur and innovation have a close relationship with each other and the outcomes of this relationship result in improvement of process and product. Cloud computing dramatically reduces technical and investment barriers to bringing new digital products, services, and processes to market (Clayton \& van Welsum, 2014).

Scheepers, Hough, and Bloom (2008) have investigated the relationship between the environment of organizational entrepreneurs and risk-taking innovation in their study, the findings showed that there is a positive relationship between the atmosphere of organizational entrepreneur and innovation.

Hossein, Alipour, and Dangalani (2015) investigate the influence of organizational entrepreneurship atmosphere on organizational innovation, the findings reveal that managerial support, the flexibility of organizational borders, accessibility of time and reward, and enabling employees affect innovation, in addition, results show that the atmosphere of organizational entrepreneurship has a meaningful effect on the organizational innovation.

The results of AlQudah (2018) study indicated that there is a positive impact of entrepreneurship initiatives (such as strategies, technology, resources, management support, and culture) on creativity and innovation within organizations and enterprises. According to Audretsch (2004), each technology innovation comes with a wave of new entrepreneurs and new start-ups, he further noted that entrepreneurial activity acts thru the availability and technology transmission and innovative ideas, and the existence of infrastructure that supports entrepreneurial efforts.

Entrepreneurship and creativity and innovation form a staggered feedback loop in that entrepreneurship breeds innovation and creativity and vice versa hold true (Zahra \& Covin, 2005). As per Audretsch (2004), innovation necessitates putting inventions into practice, it involves developing new processes, new products, on contrary, entrepreneurship has been identified as a concept that includes the exploitation and discovery of opportunities and it is thus exceedingly considered as the best approach to increasing innovation and creativity (Klein, 2008). This indicates that $\mathrm{DE}$ will enable the $\mathrm{SO}$ to thrust process and product innovations in organizations.

According to Yoo (2010), in this regard, digital innovation can be defined as the implementation of new components of digital and non-digital resources to produce novel products and processes, and because of the limited resources and knowledge available in general within many firms, consequently, organizations seek to 
leverage external resources to create new digital technological innovations (Lisen Selander, Henfridsson, \& Svahn, 2010).

Meanwhile, the collaboration networks of inter-firms (Schilling \& Phelps, 2007) and the boundary-spanning practices (Lindgren, Andersson, \& Henfridsson, 2008) have significant influences on innovation, thus, digital innovation typically includes multiple actors and interactions between entrepreneurship and organization. Innovation and entrepreneurship are often intertwined since several digital entrepreneurial ventures are based on digital innovation (Schilling \& Phelps, 2007; Bessant \& Tidd, 2007; Yip, 2015). Therefore, this study has developed the following hypothesis to explore the relationship between DE and TI.

\section{Hypothesis 3 (H3): DE positively affects TI (product and process)}

The conceptual model presented in Figure 2 illustrates the potential relationship between the smart organization and technology innovation. More specifically, this model conceptualized the effect of smart organization dimensions (as business intelligence, creative orientation, environment understanding, adaptation, and continuous learning) on technology innovation (namely, product and process). In addition, the model proposes the mediating role of digital entrepreneurship perceptions' in the relationship between the smart organization and technology innovation.

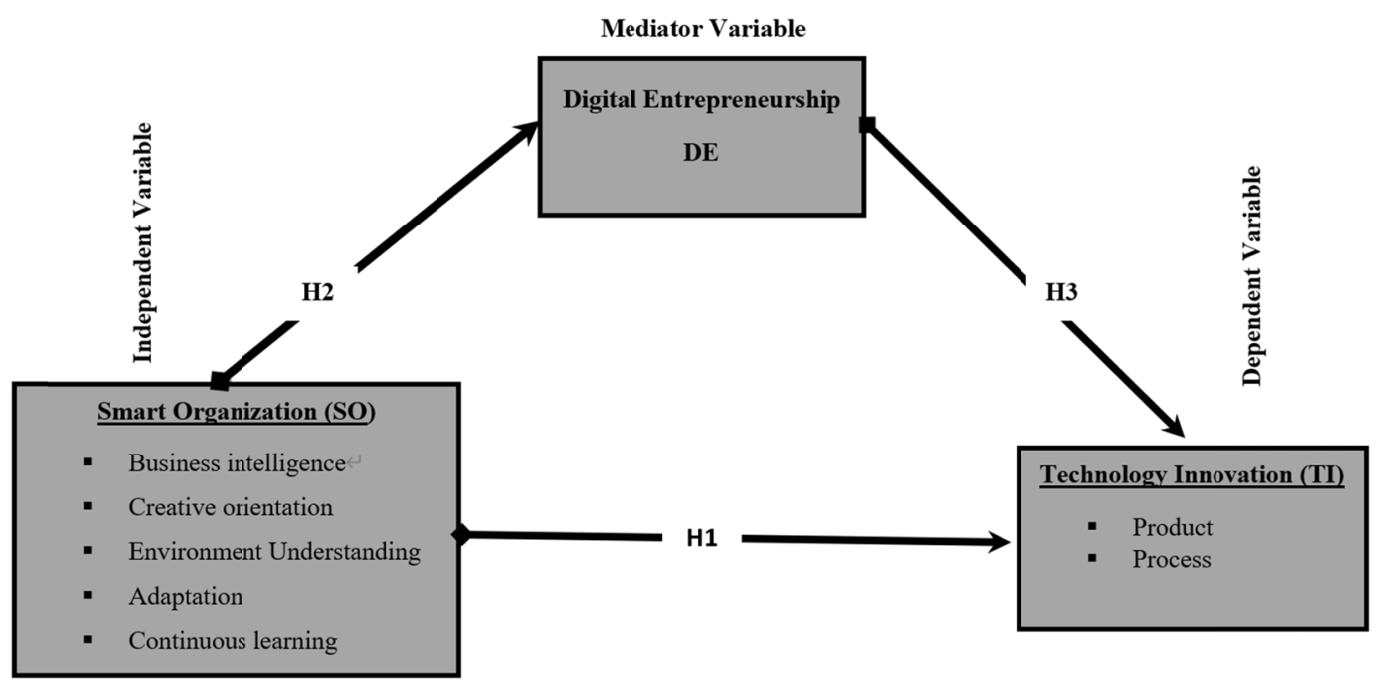

Figure 2. Smart organization-based model to technology innovation

\section{Conclusion and Future Research}

The digital revolution has transformed the meaning of entrepreneurship worldwide. The field of digital entrepreneurship researches has not been able to keep pace with the rapid changes in the digitization of our society and economy. The research purpose to evolve a valid measure of SO using business intelligence, creative orientation, environment understanding, adaptation, and continuous learning as its dimensions. The impact of these dimensions on TI (product and process) is visualized from the DE perspective is conceptualized. The need to develop an improved measure of SO and TI is due to various conceptualizations and measurements available in the related literature. This research suggests that SO characteristics can lead to the innovation of processes and products. The challenge for business organizations nowadays is to identify the role of the entrepreneurial that lead to various forms of innovations in the current environmental dynamism and intense competition and to verify the forms of these phenomenon (e.g., SO and DE) that produce the best outcomes for their corporations. There are many implications to the suggested model that should be specified before the discussion of its implications. First, in spite of its intentionally generic orientation, however, the model may not be applicable to all enterprises.

Specifically, it is intended to characterize the causes and consequences of entrepreneurship within a specific type of organization (i.e., SO) and is, therefore, might not apply to small/medium size new ventures, but rather in large and multinational firms. Second, while the model components are clearly specified, many of them represent wide constructs that operate at a high level of generality. For instance, the dissimilarity in terms of the 
definition and elements of smart organization between scholars and researchers can make it difficult to specifically incorporate it in a single model.

A primary theoretical implication is that firms can and should be seen as smart and entrepreneurial entities. Innovation is the only common theme underlying all forms of corporate entrepreneurship and smart organization. Thus, it is a defensible and meaningful assertion based on the fact that smart organization characteristics and entrepreneurship are closely related to various types of innovations, including technological innovation (Al Qudah, 2018; Al Shobaki et al., 2018).

Another implication is that many fundamental antecedents affect innovation within smart organization. To be more specific, because of the numerous and complex interrelationships between smart organization and entrepreneurship, management must focus, to the extent possible, on intangible resources that supports and helps sustain effective performance and innovativeness capacity. Thus, this would require consideration of the two main aspects (i.e., smart organization and entrepreneurship) and their direct effect and indirect effect on technology innovation. The suggested model has value in that it conceptualizes the two and their direct and indirect impacts on product and process innovations due to the lack of studies in this field.

Conducting further empirical studies in the future to validate the proposed model as well as analyzing the impact of the smart organization on technology innovation thru the mediating of digital entrepreneurship represents a promising research path within the context of business organizations in several industries.

\section{References}

Adnisi, M. (2003). The Relationship between Corporate Entrepreneurship, market Orientation, Organizational Flexibility and Job Satisfaction. Thesis in the University of Pretoria etd-MP.

Ahmadi, M., \& Ranjbari, M. (2013). Organizational Intelligence effect on entrepreneurship improvement (A case study research). TJEAS Journal, 3(13), 1311-1317.

Al Qudah, M. A. (2018). The Impact of Entrepreneurship Initiatives in Enhancing Creativity and Innovation. International Journal of Business and Management, 13(7), 157-168. https://doi.org/10.5539/ijbm.v13n7p157

Al Shobaki, M. J., Samy, S. A. N., Youssef, M. A. A., \& Suliman, A. E. T. (2018). The Availability of Smart Organization Dimensions in Technical Colleges in Palestine. International Journal of Engineering and Information Systems (IJEAIS), 2(1), 49-64.

AL-Shubiri, F. N. (2012). Measuring the impact of business intelligence on performance: An empirical study. Polish Journal of Management Studies, 6, 162-173

Andreas, K., Tobias, K., Patrick, K., \& Christoph, S. (2017). Understanding, differentiating and measuring opportunity recognition and opportunity exploitation. International Journal of Entrepreneurial Behavior \& Research, 23(1), 78-97. https://doi.org/10.1108/IJEBR-12-2015-0290

Atos. (2011). White paper: Smart Organizations - Creating Real Business Value from Connections, Content and Collaboration. Atos Origin SA.

Audretsch, D. (2004). Sustaining Innovation and Growth: Public Policy Support for Entrepreneurship. Industry and Innovation, 11(3), 167-191. https://doi.org/10.1080/1366271042000265366

Cepeda-Carrion, G., Cegarra-Navarro, J. G., \& Jimenez-Jimenez, D. (2012). The effect of absorptive capacity on innovativeness: Context and information systems capability as catalysts. British Journal of Management, 23, $120-129$.

Chan, S. (2006). Knowledge Management in Smart Organizations. In I. Mezgar (Ed.), Integration of ICT in Smart Organizations (pp. 101-136). Idea Group Publishing. https://doi.org/10.4018/978-1-59140-390-6.ch004

Clayton, T., \& van Welsum, D. (2014). Closing the Digital Entrepreneurship Gap in Europe: Enabling Businesses to Spur Growth. The Conference Board, Executive Action Report 425, The Conference Board, New York.

Damanpour, F. (1991). Organizational innovation: A meta-analysis of effects of determinants and moderators. Academy of Management Journal, 34(3), 555-590. https://doi.org/10.5465/256406

Damanpour, F., \& Aravind, D. (2011). Managerial Innovation: Conceptions, Processes, and Antecedents. Management and Organization Review, 8, 423-454. https://doi.org/10.1111/j.1740-8784.2011.00233.x 
Damanpour, F., \& Daniel, W. J. (2006). Research on Innovation in Organizations: Distinguishing Innovation-Generating from Innovation-Adopting Organizations. Journal of Engineering and Technology Management, 23(4), 269-291. https://doi.org/10.1016/j.jengtecman.2006.08.002

Damanpour, F., \& Evan, W. M. (1984). Organizational Innovation and Performance: The Problem of “Organizational Lag”. Administrative Science Quarterly, 29, 392-409. https://doi.org/10.2307/2393031

Damanpour, F., Walker, R. M., \& Avellaneda, C. N. (2009). Combinative Effects of Innovation Types and Organizational Performance: A Longitudinal Study of Service Organizations. Journal of Management Studies, 46, 650-675. https://doi.org/10.1111/j.1467-6486.2008.00814.x

Davenport, T. H., \& Kirby, J. (2015). Beyond automation. Harv. Bus. Rev., 93, 58-74.

Davidson, E. E. V. (2010). Digital Entrepreneurship and Its Sociomaterial Enactment (pp. 1-10). 2010 43rd Hawaii International Conference on System Sciences, Honolulu, HI, USA. https://doi.org/10.1109/HICSS.2010.150

Demircioglu, M. A. (2016). Organizational Innovation. In Global Encyclopedia of Public Administration, Public Policy, and Governance (pp. 1-5). https://doi.org/10.1007/978-3-319-31816-5_3017-1

Ebert, C., \& Duarte, C. H. C. (2018). Digital transformation. IEEE Softw., 35, 16-21. https://doi.org/10.1109/MS.2018.2801537

El Bassiti, L., \& Ajhoun, R. (2013). Toward an innovation management framework: A life-cycle model with an idea management focus. International Journal of Innovation, Management and Technology, 4(6), 551-559. https://doi.org/10.7763/IJIMT.2013.V4.460

El Haiba, M., Elbassiti, L., \& Ajhoun, R. (2017). Idea Management: Idea Generation Stage with a Qualitative Focus. Journal of Advanced Management Science, 5(4), 271-278. https://doi.org/10.18178/joams.5.4.271-278

Elerud-Tryde, A., \& Hooge, S. (2014). Beyond the generation of ideas: Virtual idea campaigns to spur creativity and innovation. Creativity and Innovation Management, 23(3), 290-302. https://doi.org/10.1111/caim.12066

Elisabeth, S. C., Berger, F. B., \& PerDavidsson, A. K. (2020). Digital or not: The future of entrepreneurship and innovation: Introduction to the special issue. Journal of Business Research, 125, 436-442. https://doi.org/10.1016/j.jbusres.2019.12.020

Faroun, M. T., Al-Anzi, S. A., \& Al-Khaldi, A. K. (2015). Formulating an Entrepreneurial Strategy to Develop a Model for Smart Organizations: Applied Research in Mobile Communications Companies in Iraq (Zain Iraq - Asia Cell - Kork). Al-Ghary Journal of Economic and Administrative Sciences, 10(33).

Filos, E., \& Banahan, E. (2001). Towards the smart organization: An emerging organizational paradigm and the contribution of the European RTD programs. Journal of Intelligent Manufacturing, 12, 101-119. https://doi.org/10.1023/A:1011296325760

Giones, F., \& Brem, A. (2017). Digital technology entrepreneurship: A definition and research agenda. Technol. Innov. Manag. Rev., 7(5), 44-51. https://doi.org/10.22215/timreview/1076

Gohmann, S. F. (2012). Institutions, latent entrepreneurship, and self-employment: An international comparison. Entrep. Theory Pract., 36(2), 295-321. https://doi.org/10.1111/j.1540-6520.2010.00406.x

Gozde, S.-G., \& Duygu, G. E. (2016). The Relationship and Effect between Lifelong Learning Tendencies and Social Entrepreneurship Characteristics of Prospective Teachers. Anthropologist, 24(1), 113-118. https://doi.org/10.1080/09720073.2016.11891996

Hossein, S., Abedin, A., \& Somaye, S. D. (2015). Investigation of the effect of organizational Entrepreneurship atmosphere on organizational innovation (Case Study: General office of economic and finance in Golestan province). J. Appl. Environ. Biol. Sci., 5(9S), 174-179.

Irwin, C., \& Cichocki, P. (2011). Organization Design, a Guide to Building Effective Organizations. London: Kogan Page.

Jayani Rajapathirana, R. P., \& Yan, H. (2018). Relationship between innovation capability, innovation type, and firm performance. Journal of Innovation and Knowledge (JIK), 3(1), 44-55. https://doi.org/10.1016/j.jik.2017.06.002

Joshua, A., \& Hanlie, S. (2020). The Characteristics of Digital Entrepreneurship and Digital Transformation: A 
Systematic Literature Review (pp. 239-251). Published by Springer Nature Switzerland AG 2020 M. Hattingh et al. (Eds.): I3E 2020, LNCS 12066. https://doi.org/10.1007/978-3-030-44999-5 20

Kandil, A. M. R., Abdul, A., Nebras, K., Al-Tarfy, A. H. F., \& Al-Shammari, A. A. (2019). The Role of Smart Organization Characteristics in Promoting Entrepreneurial Alertness by Adopting Proactive Work Behaviors. In The Iraqi Magazinje for Managerial Sciences (pp. 271-309).

Klein, P. (2008). Opportunity Discovery, Entrepreneurial Action, and Economic Organization. Strategic Entrepreneurship Journal, 2, 175-190. https://doi.org/10.1002/sej.50

König, M., Ungerer, C., Baltes, G., \& Terzidis, O. (2019). Different patterns in the evolution of digital and non-digital ventures' business models. Technological Forecasting and Social Change, 146(1), 844-852. https://doi.org/10.1016/j.techfore.2018.05.006

Kraus, S. et al. (2019). Digital entrepreneurship: A research agenda on new business models for the twenty-first century. Int. J. Entrep. Behav. Res., 25, 353-375.

Liliya, S., \& Gerald, S. (2020). Digital Entrepreneurship and its Role in Innovation Systems: A Systematic Literature Review as a Basis for Future Research Avenues for Sustainable Transitions. Sustainability MDPI, 12(7), 1. https://doi.org/10.3390/su12072764

Lindgren, R., Andersson, M., \& Henfridsson, O. (2008). Multi-contextuality in boundary-spanning practices. Information Systems Journal, 18(6), 641-661. https://doi.org/10.1111/j.1365-2575.2007.00245.x

Lisen, S., Ola, H., \& Fredrik, S. (2010). Transforming Ecosystem Relationships in Digital Innovation. Conference: Proceedings of the International Conference on Information Systems, ICIS 2010, Saint Louis, Missouri, USA, December 12-15.

Lumpkin, G. T., \& Dess, G. G. (1996). Clarifying the entrepreneurial orientation construct and linking it to performance. Academy of Management Review, $135-172$. https://doi.org/10.5465/amr.1996.9602161568

Majchrzak, A., \& Markus, M. L. (2014). Technology Affordances and Constraints Theory (of MIS). In E. Kessler (Ed.), Encyclopedia of Management Theory (pp. 832-836). Thousand Oaks, CA: SAGE Publications.

Mark, A. S. (2009). Organizational IQ: Characteristics Common to Smart Organizations and Applicability to the U.S. Military. MASTER OF BUSINESS ADMINISTRATION from the NAVAL POSTGRADUATE SCHOOL, USA. https://doi.org/10.21236/ADA514252

Matheson, D., \& Matheson, J. (1997). The Smart Organization: Creating value through strategic R\&D. Boston, Massachusetts: Harvard Business School Press.

Matheson, D., \& Matheson, J. (2001). Smart Organizations Perform Better: The "high-IQ" organization has almost five times the chance of being a top performer than its low-IQ counterpart. Research-Technology Management, 44(4), 49-54. https://doi.org/10.1080/08956308.2001.11671442

Matt, C., Hess, T., \& Benlian, A. (2015). Digital Transformation Strategies. Business \& Information Systems Engineering, 57(5), 339-343. https://doi.org/10.1007/s12599-015-0401-5

Mohammed, M. A.-K., Saleh, A. M. A.-K., \& Abeer, A.-F. (2016). Smart Organization Characteristics and its Impact on Social and Environmental Performance: An Empirical Study on Jordan Phosphate Mines Company. International Journal of Business and Management, 11(8), 106 https://doi.org/10.5539/ijbm.v11n8p106

Nambisan, S. (2017). Digital entrepreneurship: toward a digital technology perspective of entrepreneurship. Entrep. Theory Pract., 41, 1029-1055. https://doi.org/10.1111/etap.12254

Nuno, C., \& Arnaldo, C. (2019). The influence of Business Intelligence capacity, network learning and innovativeness on startup performance. Journal of Innovation \& Knowledge, 4(3), 139-145. https://doi.org/10.1016/j.jik.2018.03.009

Onizat, M. A., \& Alraggad, M. A. K. (2020). The Role of Knowledge Management and Technological Innovation in the Performance of New Product Development: An Empirical Study. International Journal of Business and Management, 15(7), 10-19. https://doi.org/10.5539/ijbm.v15n7p10

Parviainen, P., Kääriäinen, J., Tihinen, M., \& Teppola, S. (2017). Tackling the digitalization challenge: How to benefit from digitalization in practice. Int. J. Inf. Syst. Proj. Manag., 5, 63-77. 
Petković, M., \& Lukić, J. (2013). The Impact of Information Technology on Organizational Design: Example in Healthcare Organization. Sociologija, 55(3), 439-460. https://doi.org/10.2298/SOC1303439P

Petković, M., \& Lukić, J. (2014). New Organizational Forms Supported by the Information and Communication Technology: The Case of Serbian ICT Industry. Facta Universitatis - Economics and Organization, 11(2), 101-115.

Rashidi, R. et al. (2013). Presenting a butterfly ecosystem for digital entrepreneurship development in knowledge age. In 7th International Conference on Application of Information and Communication Technologies. IEEE, Baku. https://doi.org/10.1109/ICAICT.2013.6722798

Satalkina, L., \& Steiner, G. (2020). Digital Entrepreneurship and its Role in Innovation Systems: A Systematic Literature Review as a Basis for Future Research Avenues for Sustainable Transitions. Sustainability, 12(7), 1-27. https://doi.org/10.3390/su12072764

Scheepers, M. J., Hough, J., \& Bloom, J. Z. (n.d.). Nurturing the corporate entrepreneurship capability. Southern African Business Review, 12(3), 50-75.

Schilling, M. A., \& Phelps, C. C. (2007). Inter firm collaboration networks: The impact of large-scale network structure on firm innovation. Management Science, 53(7), 1113-1126. https://doi.org/10.1287/mnsc. 1060.0624

Shan et al. (2016). Entrepreneurial orientation and performance: Is innovation speed a missing link? Journal of Business Research, 69, 683-690. https://doi.org/10.1016/j.jbusres.2015.08.032

Soltani, S., Azadi, H., \& Witlox, F. (2013). Technological innovation drivers in rural small food industries in Iran. Journal of International Food \& Agribusiness Marketing, 25(1), 68-83. https://doi.org/10.1080/08974438.2013.726194

Starr, J. A., \& Fondas, N. (1992). A Model of Entrepreneurial Socialization and Organization Formation. Entrepreneurship Theory and Practice, 17, 1. https://doi.org/10.1177/104225879201700108

Štefan, B. (2001). Business and Managerial Start-ups, R\&D, and Product Innovation in Slovenia. Eastern European Economics, 39(4), 53-89. https://doi.org/10.1080/00128775.2001.11040998

Stock, R. M., \& Reiferscheid, I. (2014). Who should be in power to encourage product program innovativeness, R\&D or marketing? Journal of the Academic Marketing Science, 42, 264. https://doi.org/10.1007/s11747-013-0354-5

Teece, D., Peterar, M., \& Leih, S. (2016). Dynamic capabilities and organizational agility: Risk, uncertainty, and strategy in the innovation economy. California Management Review, 58(4), 13-35. https://doi.org/10.1525/cmr.2016.58.4.13

Van derAa, W., \& Elfring, T. (2002). Realizing innovation in services. Scandinavian Journal of Management, 18(2), 155-171. https://doi.org/10.1016/S0956-5221(00)00040-3

Veugelers, R. (2008). The role of SMEs in innovation in the EU: A case for policy intervention? Review of Business and Economics, 53(3), 239-262.

Vickers, M. (2000). Clever Versus Intelligent Organizations: case from Australia. Academy of Management Executive, 14(3), 135-136. https://doi.org/10.5465/ame.2000.4474566

Visnjic, I., Weingarten, F., \& Neely, A. (2016). Only the brave: Product innovation, service business model innovation, and their impact on performance. Journal of Product Innovation Management, 33(1), 36-52. https://doi.org/10.1111/jpim.12254

Von Briel, F., Davidsson, P., \& Recker, J. (2018a). Digital Technologies as External Enablers of New Venture Creation in the IT Hardware Sector. Entrepreneurship Theory and Practice, 42(1), 47-69. https://doi.org/10.1177/1042258717732779

Von Briel, F., Recker, J., \& Davidsson, P. (2018b). Not All Digital Venture Ideas Are Created Equal: Implications for Venture Creation Processes. Journal of Strategic Information Systems, 27(4), 278-295. https://doi.org/10.1016/j.jsis.2018.06.002

Wasterman, G., Bonnet, D., \& McAfee, A. (2014). Leading digital: Turning technology into business transformation. Boston: Harvard Business Review Press.

Yip, G. (2015). The 'three phases' of Chinese innovation. Retrieved March 28, 2016, from http://www.forbes.com/sites/ceibs/2015/03/23/the-three-phases-of-chinese-innovation/ 
Youngjin, Y., Richard, J. B., Kalle, L., \& Ann, M. (2012). Organizing for Innovation in the Digitized World. Organization Science, 23(5), 1398-1408 https://doi.org/10.1287/orsc.1120.0771

Zahra, S. A., \& Covin, J. C. (2005). Contextual influences on the corporate entrepreneurship performance relationship: A longitudinal analysis. Journal of Business Venturing, 10(1), 43-58. https://doi.org/10.1016/0883-9026(94)00004-E

\section{Copyrights}

Copyright for this article is retained by the author, with first publication rights granted to the journal.

This is an open-access article distributed under the terms and conditions of the Creative Commons Attribution license (http://creativecommons.org/licenses/by/4.0/). 